\title{
Bioindicator Emerged as a Potential Environmental Marker
}

\author{
Sudeepta Pattanayak*, Siddhartha Das and Kuna Navyasri
}

Department of Plant Pathology, MS Swaminathan School of Agriculture, Centurion University of Technology and Management, Paralakhemundi, Odisha, India

"Corresponding author: sudeepta.chiki@gmail.com (ORCID ID: 0000-0002-0262-8219)

Paper No. 854

Received: $15-04-2020$

Revised: $21-07-2020$

Accepted: 27-08-2020

\begin{abstract}
In the era of modern science and new technology, mankind is adopting new and novel approaches to deal with the problems. The high population density and urbanization has changed our environment to a polluted one. Its not easy to deal with this problem with complex and costly equipment. Bioindicators are playing a major role in reducing the pollution and to check it timely without any environmental hazard. Bioindicators are the living organism which facilitate in reduction of the environmental pollution. They directly or indirectly determine the amount of pollutants and contaminants present in our ecosystem. They rapidly react to their surrounding environment and give us early warning. These can be used for indexing the health of the ecosystem as well as balancing the ecosystem without any disturbance in food chain. Biomonitoring is one of the promising and cost-effective methods as compared to other techniques. More researches are highly needed to explore the hidden characteristics and many more new species which will help us to build a better and safe environment.

\section{Highlights}

(0 Environmental pollution can be checked by using the potential bioindicators which are may be plant, animal or microorganisms.

(0 Being sensitive and specific, these bioindicators react against the slight change of the surrounding environment by increasing or decreasing the population density.

0 Bioindicators not only restricted as environmental marker, but also widely diversified to help in search of specific species population, natural resources and extinct phylogenetic trend line.
\end{abstract}

Keywords: Bioindicator, Environment, Pollution, Monitoring, Contamination

The world population is increasing drastically from past years and so population. These high population densities, industrialization, deforesting, urbanization etc. has made our environment contaminated and polluted (Rakshit et al. 2017). Not only human health but also animal and plant health are in very problematic situation now. In this contemporary period, many discoveries have made to build modern equipment with novel ideas. But those are not popular yet due to their high cost. Another novel discovery i.e. bioindicators has opened the path to monitor and indicate the pollution and contamination of our environment. These bioindicators can be defined as an indicator of environmental pollution or contamination by using living organisms such as micro-organisms (bacteria, fungi, algae, lichen etc.), plants, animals etc (Fig. 1). The small change of the environmental health can easily be recognized by those indicators. Reduction in population of this bioindicators was observed many a times due to high pollution or any physical, chemical, physiological and behavioral change of our ecosystem. Sometimes many plant and animal species become endangered for the environmental changes. Those bioindicators are very specific against a specific change in the environment. Thus,

How to cite this article: Pattanayak, S., Das, S. and Navyasri, K. (2020). Bioindicator Emerged as a Potential Environmental Marker. IJAEB, 13(3): 339-344.

Source of Support: None; Conflict of Interest: None 
before selecting a bioindicator for a specific reason, it should be studied priorly and properly.

These bioindicators in an aggregate form determine both the positive and negative impact of the environment (Peterson 1986; Holt and Miller 2010). The existence of the bioindicators can be known by several factors such as temperature, water quality and light transmission etc. They indicate the cumulative positive or negative impact on soil or water bodies due to long term exposure of any pollutant such as herbicide exposure can be observed in case of low photosynthesis of marine plants.

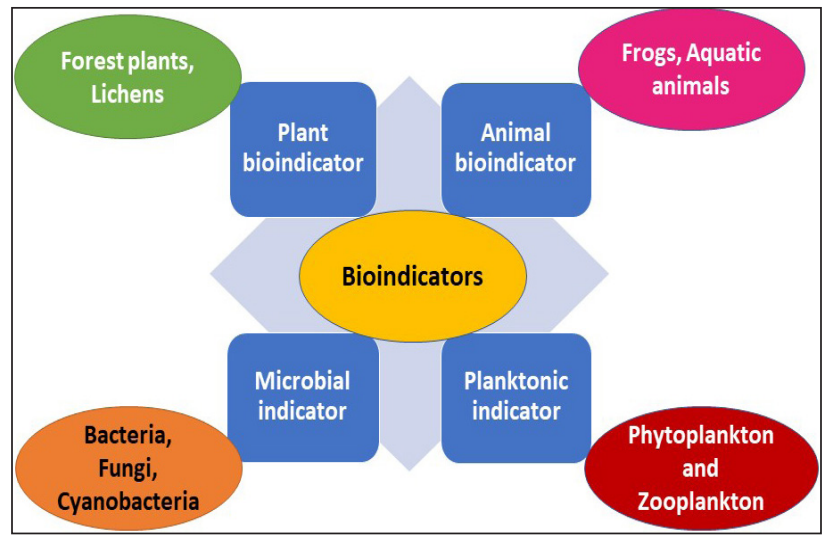

Fig. 1: Different types of bioindicators with example

\section{Criteria and characterization for selection of bioindicator}

- Easily available

- Cost effective

- All season availability in a wide range of area

- Resistance against unfavorable climatic condition

- Sensitive towards a specific dose of contaminants

- High reproductive rate

- Harmless to environment

\section{Biomonitoring}

Monitoring the environment health by using bioindicators or living organisms is known as biomonitoring. Bio monitors give the quantitative data regarding the environmental quality and impact of several pollutants on it. Biomonitoring can be done in various ways aiming the slight modification of the environmental health (Marques 2001). The effect of specific stressors on environment is taken in to consideration. It is also a promising method to determine the water quality. These are available all over the world. All bio monitors can be referred as bioindicators to some extent but the most promising are planktons.

\section{Different types of bioindicators}

\section{(i) Microbial Bioindicator}

Micro-organisms are taking a major portion of aquatic biomass. The rate of multiplication is also high and they are easily available than macroorganisms. Microbial bioindicators can be referred as the micro-organisms which is used to indicate the health of terrestrial and aquatic eco-system (Klemm 1990). These micro-organisms are very sensitive against small quantity of toxics and contaminants by which they can react to small change in the quality of oceanic ecosystem (Hans et al. 2003; Hosmani 2014). An early warning is observed due to the stress protein secreted by micro-organisms when they are exposed to contaminants containing benzene and cadmium. The bioluminescent bacteria can be used as an indicator to check the toxin level. If high toxin level, then disruption in cellular metabolism is observed by which the light emittance decreases. It was reported that Vogesella indigofera can produce blue pigments in absence of any metals while the pigmentation is blocked due to the presence of hexavalent chromium (Arora 1966; Jain et al. 2010).

\section{(ii) Plant Bioindicator}

The increase in industries and population is directly and indirectly playing an important role in environmental pollution (Batiuk et al. 1992). Several plant species mainly marine plants are known to reduce the contamination to a greater extent. These marine plants are immobile in nature. Lichen, the mutualism between algae and fungi mainly grow on the trunks of forest plants. The slighter modification in forest air quality, climate and structure can be known by the reaction of lichen. Sometimes, the lichens disappear from the forest ecosystem due to environmental stress like increase in toxic gas content. Phacus tortus, Euglena clastica are used as the indicator of contamination in marine ecosystem. Higher plants like Agrost spp., Anthroxanthum spp., Festuca spp. are known to indicate copper, zinc and lead respectively. Similarly, lower plants like 
lichens can indicate the existence of Sulphur dioxide and fluorine content, ozone gas, radionuclides like cesium-17, strontium-30 etc.

\section{Morphological and physiological response of plants against environmental pollution}

Major visible morphological and physiological modifications can be observed due to several disturbances in the surrounding environment. These visible changes are due to intolerance of a plant against the environmental condition. Premature leaf losses can be observed due to air pollution like Sulphur dioxide and cement-kiln dust (Lerman and Darley 1975). Irregular formation of leaves and flowers was reported due to high number of radionuclides such as carnorite and monazite in soil (Nair 1961; Osborn 1961). Mis formation of petals in Papaver macrostomum and dwarfism in coniferous plants was observed due to heavy lead content in soil. Several biotic and abiotic factors directly or indirectly affect the tree ring width or wood biomass (Fritts 1976). Long term exposure to Sulphur dioxide and heavy metals can result reduced ring width (Lux 1965; Grill et al. 1979). Exposure to high concentration of ozone and hydrocarbons can result chlorosis Picea abies and Pinus sylvestris (Utriainen and Holopainen 1998; Schroder 1998).

\section{(iii) Animal Bioindicator}

Animals are playing an important role as a bioindicator by reacting to the contaminated environment in several ways. The changes in environment directly affect the animal population density and disturb the food chain. These animals also help to indicate any toxin present in their cell (Joanna 2006). Frogs are major bioindicators showing any changes in aquatic and terrestrial environment. The invertebrates living in the bottom layer of aquatic environment are most potential indicators reacting against the quality of water body (Khatri and Tyagi 2015). Blue mussel, a widely distributed organism in ocean was used to indicate the costal water pollution by any metals. Their high availability, proper monitoring has made them as a good bioindicator. Earthworms are reported to indicate high radioactive pollution in soil while marine animals determine the health of water body.

These population densities of animal bioindicators increase or decrease in response to the surrounding population change. The toxic chemical or heavy mental content directly affect the animal tissue. The physiological, morphological and behavioral changes also determine the quality of the environment.

\section{(iv) Planktonic Bioindicator}

Planktons are playing a crucial role in monitoring the pollution of water bodies mainly in lakes. They can be referred as best markers for determining the water health. They can also facilitate the decomposition of organic wastes in water body. The accumulation of phosphorus and nitrogen make the water poor by increasing the population density of planktons which creates major problem in managing the water body. In this situation, fish feed upon the planktons to maintain the balance in water bodies. Some plankton like cyanobacteria produces toxins which mix in water and make the water quality poor.

\section{(a) Phytoplankton}

Phyto planktons are the aquatic plant and produce their food through photosynthesis. These are also known as microalgae and found mostly as freely floating on the ocean. The amount of sunlight is playing a crucial role in their life to produce food. As an indicator, their population decreases due to the contamination of water bodies (Table 1). It was observed that industrial effluents or any colored or solids pollutants are mixed in water, then the growth of phytoplankton decreases highly due to infiltration of sunlight. Additionally, the reduced amount of sunlight can directly affect the uptake of ammonia and nitrate in phytoplankton (Walsh 1978).

\section{(b) Zooplankton}

The microscopic animals of water bodies are known as zooplanktons. They can be found near the water surface and are poor swimmers. Phytoplankton, Bacterioplankton and marine snow are the main food of zooplanktons. These zooplanktons help in determining the water quality (Table 2). In addition to this they can give an early warning about eutrophication. The potential zooplanktons are dependent on many abiotic factors such as temperature, stratification and biotic factors such as predation, competition for their growth and development (Ramachandra et al. 2006). 
Table 1: Phytoplankton indicating different types of contamination

\begin{tabular}{|c|c|c|c|}
\hline Phytoplankton & Indications & Mechanism & Reference \\
\hline Chlorella vulgaris & $\begin{array}{l}\text { Low concentration of heavy } \\
\text { metal contamination in water } \\
\text { bodies }\end{array}$ & $\begin{array}{l}\text { Interfere the glycollate production or inhibit } \\
\text { secondary metabolite to stimulate growth by } \\
\text { preventing carbon loss }\end{array}$ & $\begin{array}{l}\text { De Filippis and } \\
\text { Palaghy 1976; } \\
\text { Lilian } 2009\end{array}$ \\
\hline Green algae & Controls the fish growth & $\begin{array}{l}\text { Excessive colonization of green algae leads to } \\
\text { eutrophication causing the fish death }\end{array}$ & $\begin{array}{l}\text { Khatri and Tyagi } \\
2015\end{array}$ \\
\hline Mosses & Metal contamination & $\begin{array}{l}\text { Excessive metal abundance leads to restricted } \\
\text { photosynthesis which result reduced population } \\
\text { density }\end{array}$ & Uttah et al. 2008 \\
\hline Wolffia globosa & Cadmium toxicity & $\begin{array}{l}\text { This chemical effluent blocks the effect of light } \\
\text { causing restricted growth of this phytoplankton. }\end{array}$ & $\begin{array}{l}\text { Walsh 1978; Uttah } \\
\text { et al. } 2008\end{array}$ \\
\hline
\end{tabular}

Table 2: Zooplankton indicating different types of contamination

\begin{tabular}{|c|c|c|c|}
\hline Zooplankton & Indications & Mechanism & Reference \\
\hline Brachionus dolabrotus & $\begin{array}{l}\text { Increase in water } \\
\text { turbidity due to } \\
\text { sediments }\end{array}$ & $\begin{array}{l}\text { High water turbidity leads to decreased larval } \\
\text { population }\end{array}$ & $\begin{array}{l}\text { Grizzle 1984; Salonen et } \\
\text { al. } 2009\end{array}$ \\
\hline $\begin{array}{l}\text { Unspecified spp. of } \\
\text { Cladocerans }\end{array}$ & $\begin{array}{l}\text { Number of contaminants } \\
\text { in water }\end{array}$ & \multirow{3}{*}{$\begin{array}{l}\text { Heavy chemical contamination directly affects } \\
\text { the arthropod population resulting reduced } \\
\text { reproduction rate and direct mortality }\end{array}$} & Hosmani 2014 \\
\hline Leeches & $\begin{array}{l}\text { Contamination of water } \\
\text { bodies }\end{array}$ & & Uttah et al. 2008 \\
\hline Oyster & Lead contamination & & Uttah et al. 2008; \\
\hline Rotatoria & Eutrophication & $\begin{array}{l}\text { Depletion of oxygen directly reduce the growth } \\
\text { and reproduction of this spp. }\end{array}$ & Markert et al. 2003 \\
\hline $\begin{array}{l}\text { Cladocerans (Daphina, } \\
\text { Bosmina, Moina) }\end{array}$ & Quality of marine health & $\begin{array}{l}\text { Accumulation of larger amount of photodieldrin } \\
\text { (Chlorinated epoxide derivative) which cause } \\
\text { them sensitive to metal toxicity }\end{array}$ & $\begin{array}{l}\text { Khan and Khan 1974; } \\
\text { Aslam et al. } 2012\end{array}$ \\
\hline Copepods & Quality of marine health & $\begin{array}{l}\text { Rate of growth reduced due to limited egg } \\
\text { production }\end{array}$ & Aslam et al. 2012 \\
\hline Brachionus calyciflorus & $\begin{array}{l}\text { Eutrophication and } \\
\text { pollution of water bodies } \\
\text { by organic wastes }\end{array}$ & $\begin{array}{l}\text { Depletion of oxygen directly reduces the growth } \\
\text { and reproduction of this spp. and low population } \\
\text { density observed due to lack of proper nutrients. }\end{array}$ & Jain et al. 2010 \\
\hline
\end{tabular}

The population of zooplankton depends on several factors like rate of predation, amount of effluents presents in water etc. The rate of increase population of zooplankton is given below (Walsh 1978):

Rate of increased population of zooplankton = Change rate with out any predation or pollutionpredation rate- loss rate due to the effect of pollution

\section{Advantage and significance of bioindicator}

The advantages and significance of bioindicators are described below:

- To test the contamination and toxic level of water body or environment, several techniques and equipment are needed. But the use of 
Bioindicators may reduce the cost of complex techniques.

- Their high reproducible nature is crucial for the indication of toxic level.

- The sensitivity towards the contaminants facilitates easy monitoring of toxic effluents or contaminants in the environment.

- It gives early warning of contamination in water bodies.

- These bioindicators are potentially effective against a wide range of pollutants.

- There is no harmful effect on the environment.

\section{Significance}

- These bioindicators can be used in various fields such as in animal tissues to water bodies.

- Planktonic indicators playing a major role in determining the health status of aquatic ecosystem.

- These indicators conserve the natural resources by indicating any toxic substances present in our ecosystem.

- They check the natural cleanup process like presence of contaminants in drinking water.

- These are very practical in determining the environment health.

\section{CONCLUSION AND FUTURE SCOPE}

The pollution of our environment has major impact on our ecosystem. The remarkable bioindicators potentially forecast any upcoming disasters and preserve natural resources by preventing pollution. These can also facilitate sustainable development of environment without any negative impact. In addition to this, it checks the health of water bodies by monitoring the infiltration of industrial substances in water bodies. These are very promising by reacting to any physical, physiological and behavioral changes of the environment. Their use is very cost effective and reliable. They are very sensitive against any slight modification and give early warning by reducing or increasing their population density or changing the color of the coral.

In near future, the demand of these indicators will increase highly. Therefore, researchers should focus on discovering new species of bioindicators and their negative and positive impact towards environment. Many existing bioindicators are studied in experimental level only. So, it should be practically studied before applying in field level. More studies should be conducted for reducing the damage to the bioindicators by any toxic metabolites. Till now, many bioindicators have proved in field level but commercial production is lacking. Government must take steps to increase its use, to popularize and to produce it in commercial scale. Before releasing any of the product in market, regulations should be fixed by the government for its use in field level. Industrialization and heavy chemical use in agriculture have increased the toxics in water bodies. Scientists should focus on exploring new bioindicators which will be helpful in reducing the chemicals of water bodies. It is not possible to make our environment free from pollution, but it is not difficult to timely monitor the pollution and to take proper steps to reduce it so that in near future a sustainable environment will be built.

\section{REFERENCES}

Arora, H.C. 1966. Rotifer as indicators of trophic nature of environments. J. Hydrobiologia., 27(1-2): 146-159.

Aslam, M., Verma, D.K., Dhakerya, R., Rais, S., Alam, M. and Ansari, F.A. 2012. Bioindicator: a comparative study on uptake and accumulation of heavy metals in some plants leaves of M.G. Road, Agra City, India. Res. J. Environ. Earth Sci., 4(12): 1060-1070.

Batiuk, R.A., Orth, R.J., Moore, K.A., Dennison, W.C., Stevenson, J.C., Staver, L.W. and Carter, V. et al. 1992. Chesapeake Bay submerged aquatic vegetation habitat requirements and restoration targets: a technical synthesis. Annapolis (MD): Chesapeake Bay Program, 83/92: 166-169.

Fritts, H.C. 1976. Tree Rings and Climate. Academic Press, New York.

Grill, D., Lieg, I.E. and Windisch, E., 1979. Holzanatomische Untersuchungen an abgasbelasteten B iumen. Phytopathologische Zeitschrift, 94: 335-342.

Grizzle, R.E. 1984. Pollution indicator species of macro benthos in a coastal lagoon. Mar. Ecol. Prog. Ser., 18: 191-200.

Hans, W., Dyble, P.J., Moisander, P.H., Noble, R.T., Piehler, M.F., Pinckney, J.L., Steppe, T.F., Twomey, L. and Valdes, L.M. 2003. Microbial indicators of aquatic ecosystem change: current applications to eutrophication studies. FEMS Microbiol Ecol., 46: 233-246.

Holt, E.A. and Miller, S.W. 2010. Bioindicators: using organisms to measure environmental impacts. Nature, 3(10): 8-13. 
Hosmani, S.P. 2013. Freshwater algae as indicators of water quality. Univers. J. Environ. Res. Technol., 3(4): 473-482.

Jain, A., Singh, B.N., Singh, S.P., Singh, H.B. and Singh, S. 2010. Exploring biodiversity as bioindicators for water pollution. National Conference on Biodiversity, Development and Poverty Alleviation; 2010 May 22, Uttar Pradesh. Lucknow (India): Uttar Pradesh State Biodiversity Board.

Joanna, B. 2006. Bioindicators: types, development, and use in ecological assessment and research. Environ. Bioind., 1: 22-39.

Khan, H.M. and Khan, M.A.Q. 1974. Biological magnification of photodieldrin by food chain organisms. Arch. Environ. Contam. Toxicol., 2: 289-301.

Khatri, N. and Tyagi, S. 2015. Influences of natural and anthropogenic factors on surface and groundwater quality in rural and urban areas. Front Life Sci., 8(1): 23-39.

Klemm, D.J. 1990. Macro invertebrate field and laboratory methods for evaluating the biological integrity of surface waters. Cincinnati $(\mathrm{OH})$ : EPA.

Lambert, S.J. and Davy, A.J. 2011. Water quality as a threat to aquatic plants: discriminating between the effects of nitrate, phosphate, boron and heavy metals on charophytes. New Phytologist., 189: 1051-1059.

Lerman, Si., Darley, E.F., 1975. Particulates. In: Mudd, J.B., Kozlowski, T.T., 1975. Responses of Plants to Air Pollutants. Academic Press, New York, pp. 141-158.

Lux, H. 1965. Ergebnisse von Zuwachsuntersuchungen (Bohrspahnanalyse) im Rauchschadengebiet Diibener Heide. Archiv fiir Forstwesen., 14: 433-442.

Markert, B.A., Breure, A.M. and Zechmeister, H.G. 2003. Chapter 1, definitions, strategies and principles for bioindication/ biomonitoring of the environment. In: Trace Metals Other Contam Environ., 6: 3-39.

Marques, J.C. 2001. Diversity, biodiversity, conservation, and sustainability. Sci. World. J., 1: 534-543.

Nair, G.G. 1961. Floral study of the sterile Crotalaria striata L. observed in the radioactive monazite sand. Transaction of the Bose Research Institute, 24: 67-72.
Osborn, W.S. 1961. Variation in clones of Penstemon growing in natural areas of differing radioactivity. Science, 134: 342-343.

Peterson, W.T. 1986. The effects of seasonal variations in stratification on plankton dynamics in Long Island Sound. In: Bowman MJ, Yentsch CM, Peterson WT, editors. Tidal mixing and plankton dynamics. Berlin: Springer-Verlag. Vol. 17. Lecture Notes in Coastal and Estuarine Studies, pp. 225-319.

Rakshit, A., Abhilash, P.C., Singh, H.B. and Ghosh, S. 2017. Adaptive soil management: From theory to practices. Springer Nature, ISBN 978-981-10-3637-8, pp. 571.

Ramchandra, T.V., Rishiram, R. and Karthik, B. 2006. Zooplanktons as bioindicators: hydro biological investigation in selected Bangalore lakes. Technical Report, 115.

Salonen, M., Uroh, L. and Engstrom-ost, J. 2009. Effects of turbidity and zooplankton availability on the condition and prey selection of pike larvae. Boreal Environment Research, 14: 981-989.

Schroder, P. 1998. Halogenated air pollutants. In: De Kok, L.J., Stulen, I. (Eds), Responses of Plant Metabolism to Air Pollution and Global Change. Backhuys, Leiden, pp. 131-145.

Utriainen, J. and Holopainen, T. 1998. Effects of elevated $\mathrm{CO}_{2}$ and $\mathrm{O}_{3}$ concentrations on dry matter partitioning, chlorophyll content and needle ultrastructure of Scots pine seedlings. In: De Kok, L.J., Stulen, I. (Eds), Responses of Plant Metabolism to Air Pollution and Global Change. Backhuys, Leiden, pp. 467-469.

Uttah, E.C., Uttah, C., Akpan, P.A., Ikpeme, E.M., Ogbeche, J. and Usip, J.O. 2008. Bio-survey of plankton as indicators of water quality for recreational activities in Calabar River, Nigeria. J Appl. Sci. Environ Manage., 12(2): 35-42.

Walsh, G.E. 1978. Toxic effects of pollutants on plankton. In: Butler GC, editor. Principles of ecotoxicology. New York (NY): Wiley. Chapter 12; p. 257-274. 